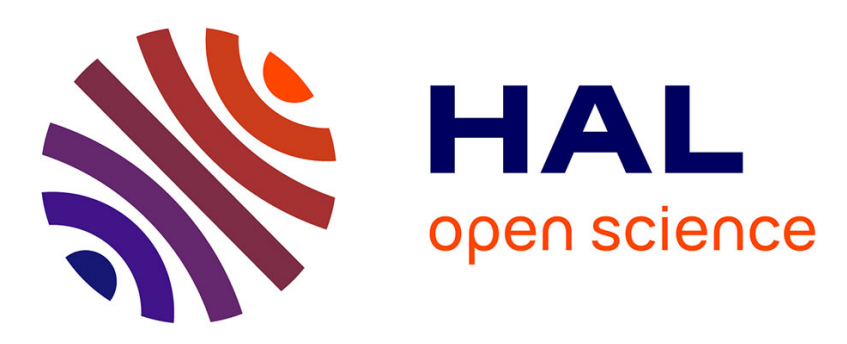

\title{
In Vitro and In Vivo Activity of Anogeissus leiocarpa Bark Extract and Isolated Metabolites against Toxoplasma gondii
}

Jérémy Spalenka, Jane Hubert, Laurence Voutquenne-Nazabadioko, Sandie Escotte-Binet, Nicolas Borie, Frederic Velard, Isabelle Villena, Laurence Voutquenne-Nazabadioko, Jean-Hugues Renault

\section{To cite this version:}

Jérémy Spalenka, Jane Hubert, Laurence Voutquenne-Nazabadioko, Sandie Escotte-Binet, Nicolas Borie, et al.. In Vitro and In Vivo Activity of Anogeissus leiocarpa Bark Extract and Isolated Metabolites against Toxoplasma gondii. Planta Medica, 2020, 86 (4), pp.294-302. 10.1055/a-1088-8449 . hal-02498431

\section{HAL Id: hal-02498431 https://hal.univ-reims.fr/hal-02498431}

Submitted on 24 Nov 2021

HAL is a multi-disciplinary open access archive for the deposit and dissemination of scientific research documents, whether they are published or not. The documents may come from teaching and research institutions in France or abroad, or from public or private research centers.
L'archive ouverte pluridisciplinaire HAL, est destinée au dépôt et à la diffusion de documents scientifiques de niveau recherche, publiés ou non, émanant des établissements d'enseignement et de recherche français ou étrangers, des laboratoires publics ou privés. 


\section{In vitro and in vivo activity of Anogeissus leiocarpa bark extract and isolated metabolites against Toxoplasma gondii}

Jérémy Spalenka ${ }^{1,2, \# a}$, Jane Hubert ${ }^{1, \# b}$, Laurence Voutquenne-Nazabadioko ${ }^{1}$, Sandie Escotte-Binet ${ }^{2}$, Nicolas Borie ${ }^{1}$, Frédéric Velard ${ }^{3}$, Isabelle Villena ${ }^{2,4}$, Dominique Aubert ${ }^{2,4}$, Jean-Hugues Renault ${ }^{*}$

${ }^{1}$ Université de Reims Champagne Ardenne, CNRS, ICMR UMR 7312, Reims, France

${ }^{2}$ Université de Reims Champagne Ardenne, ESCAPE EA 7510, Reims, France

${ }^{3}$ Université de Reims Champagne Ardenne, BIOS, EA 4691, Reims, France

${ }^{4}$ Centre National de Référence de la Toxoplasmose, CHU Hôpital Maison Blanche, Reims, France

\#a Current Address: Université de Reims Champagne Ardenne, CNRS, MEDyC UMR 7369, Reims, France

\#b Current Address: NatExplore SAS, Prouilly, France

* Corresponding author

Professor Jean-Hugues RENAULT

Université de Reims Champagne Ardenne, CNRS, ICMR UMR 7312

Campus Sciences Exactes et Naturelles - bâtiment 18 - BP 1039

51687 Reims Cedex 2, France

Phone number: +33 (0)326913403

E-mail: jh.renault@univ-reims.fr 


\section{Abstract}

Toxoplasma gondii, belonging to the Apicomplexa phylum, is a cosmopolitan protozoan parasite which affects at least $30 \%$ of the world's population. In West Africa, the leaves and bark of the tree species Anogeissus leiocarpa (DC.) Guill. \& Perr. are used against zoonosis in traditional medicine and play a key role in controlling diseases induced by Apicomplexans such as malaria. In this study, extracts, fractions and pure compounds obtained from an ethanol extract of the bark of $A$. leiocarpa were evaluated against $T$. gondii infection in vitro and in vivo. The crude bark extract showed a significant activity on tachyzoites from the $T$. gondii $R H$ strain $\left(I_{50}=59.30 \mu \mathrm{g} / \mathrm{mL}\right)$. The crude bark extract without tannins and pure trachelosperogenin $E$ purified by Centrifugal Partition Chromatography showed the highest activity $\left(\mathrm{IC}_{50} \mathrm{~S}=12.83 \mu \mathrm{g} / \mathrm{mL}\right.$ and $26.63 \mu \mathrm{g} / \mathrm{mL}$, respectively) with satisfying selectivity indexes of 9.61 and 9.75 , respectively. The crude bark extract without tannins and pure trachelosperogenin $E$ were able to significantly inhibit host cell invasion by the parasite in vitro, while the crude bark extract without tannins was able to increase mice survival in our murine model of chronic toxoplasmosis. These results provide new biological data for natural compounds that could enhance the current panoply of treatments against toxoplasmosis.

\section{Keywords}

Toxoplasma gondii, Anogeissus leiocarpa, Combretaceae, centrifugal partition chromatography, natural products, chemosensitivity.

\section{Abbreviations}

CBEWT, Crude Bark Extract Without Tannin; CPC, Centrifugal Partition Chromatography; HRP, Horseradish Peroxidase; PBS, Phosphate Buffered Saline; SAG-1, Surface Antigen 1; SI, Selectivity Index.

\section{Introduction}

Toxoplasmosis is an important parasitic disease caused by the protozoan Toxoplasma gondii. Approximately one-third of the world population have been infected by this parasite [1]. Toxoplasmosis, a generally benign affection, can nevertheless cause 
severe life-threatening disease in immunocompromised patients and in congenitally affected children [2]. The population structure of $T$. gondii consists in three main clonal lineages correlated with virulence expression in mice: type I (including $\mathrm{RH}$, a highly virulent strain in mice), type II (including avirulent strain like ME-49) and type III (avirulent strains) [3].

Only a few treatments are currently available against toxoplasmosis. They mainly consist in a synergic combination of pyrimethamine and sulfonamide and act by blocking the folate biosynthesis pathway, which is essential for parasite survival and growth. However, treatment of toxoplasmic encephalitis and chorioretinitis by these drugs may fail due to host intolerance or bad absorption of the molecules $[4,5]$. Moreover, resistant strains against sulfadiazine $[6,7]$ leads to the need for new active compounds against toxoplasmosis.

African birch (Anogeissus leiocarpa (DC.) Guill \& Perr., Combretaceae), is a large tree that mainly grows from Senegal to Sudan. Its leaves and bark are traditionally used in West Africa to treat skin diseases, coughing, asthma, fever, rheumatisms [8] and bacterial infections [9]. Its leaves, roots and bark have an in vitro activity on Plasmodium falciparum $[10,11]$. In view of these previous results, we hypothesized that the ethanol bark extract of $A$. leiocarpa could inhibit the growth of $T$. gondii, which also belongs to the Apicomplexa phylum like $P$. falciparum.

From a chemical point of view, we showed previously that the commercially-provided bark of A. leiocarpa is mostly composed of highly abundant water-soluble tannins, together with a diversity of low molecular weight metabolites including ellagic acid derivatives, flavonoids, triterpenes and saponosides [12].

The aim of this study was thus to evaluate both the in vitro and in vivo activities of an A. leiocarpa bark extract and purified compounds on Toxoplasma gondii infection.

The in vitro antitoxoplasmic activity was assessed by incubating tachyzoites of the $\mathrm{RH}$ strain with the extract for 72 hours. The crude bark extract was fractionated by centrifugal partition chromatography (CPC). The obtained chemically simplified fractions or purified compounds were chemically profiled mainly by Nuclear Magnetic Resonance and tested again in vitro on the $\mathrm{RH}$ strain tachyzoites. The most active compounds were then assessed for their inhibition effect on cell invasion by tachyzoites, and finally evaluated in vivo on a model of infected mice.

\section{Results and Discussion}


The aim of this study was to evaluate the in vitro and in vivo antitoxoplasmic activities and cytotoxicity of the ethanol (99\%) bark extract of the African tree A. leiocarpa. The fractionation of the crude extract ( $3 \mathrm{~g}$ injected) and the chemical profiling of the fractions and purified compounds were achieved by CPC and a dereplication process based on ${ }^{13} \mathrm{C}$ NMR [13], respectively. A three-phase solvent system composed of $n$ heptane, $\mathrm{MtBE}, \mathrm{CH}_{3} \mathrm{CN}$ and water was used in a sequential $\mathrm{CPC}$ elution mode in order to fractionate the different $A$. leiocarpa compounds over a large polarity range. Watersoluble tannins and sugars being the main compounds in the initial solid-liquid ethanolic crude bark extract, a $\mathrm{CH}_{3} \mathrm{CN}$ and water-rich stationary phase was selected in order to trap these highly polar compounds in the CPC column over the whole fractionation experiment. At the end of the fractionation process, 25 chemically simplified fractions or purified compounds were obtained (Table I).

The most hydrophobic compounds were eluted with the $n$-heptane rich mobile phase during the first step of the fractionation experiment (from to to $50 \mathrm{~min}$ ), representing $10.7 \%$ of the crude extract mass ( $305.5 \mathrm{mg}$, fractions $\mathrm{F}_{1}$ to $\mathrm{F}_{7}$ ).

During the second step of the CPC fractionation process (from 51 to $85 \mathrm{~min}$ ), moderately polar compounds were progressively eluted from the stationary phase to the MtBE-rich mobile phase. The corresponding fractions from $F_{8}$ to $F_{24}$ represented $16.5 \%$ of the crude extract mass $(469.9 \mathrm{mg}$ ). Water-soluble tannins and sugars were then recovered in fraction $F_{25}$ by extrusion [14] of the CPC column. This fraction represented $72.8 \%$ of the crude mass extract $(2071.9 \mathrm{mg})$. All the 25 fractions were analyzed by ${ }^{1} \mathrm{H}$ and ${ }^{13} \mathrm{C}$ NMR spectroscopy in order to identify the main class of compounds in the extract and unambiguously identify at least one major member of each class.

Six fractions $\left(\mathbf{F}_{\mathbf{5}}, \mathbf{F}_{\mathbf{7}}, \mathbf{F}_{\mathbf{1 1}}, \mathbf{F}_{\mathbf{1 3}}, \mathbf{F}_{\mathbf{1 8}}\right.$ and $\left.\mathbf{F}_{\mathbf{2 5}}\right)$ containing the main characteristic compounds of $A$. leiocarpa bark extract were selected to be tested against Toxoplasma gondii $\mathrm{RH}$ strain. Fraction $\mathbf{F}_{18}(35.2 \mathrm{mg}, 1.2 \% \mathrm{w} / \mathrm{w}$ of the extract) contained purified sericoside (1); fraction $\mathbf{F}_{13}(22.8 \mathrm{mg}, 0.8 \% \mathrm{w} / \mathrm{w}$ of the extract) contained purified ellagic acid (2); fraction $\mathbf{F}_{5}(15.7 \mathrm{mg}, 0.6 \% \mathrm{w} / \mathrm{w}$ of the extract) was approximately a $66 / 33$ (based on ${ }^{1} \mathrm{H}$ NMR signal integration) mixture of 3,3'-di-O-methylellagic acid (3) and 3,4,3'-tri-O-methylflavellagic acid (4); fraction $\mathbf{F}_{11}(28.0 \mathrm{mg}, 1.0 \% \mathrm{w} / \mathrm{w}$ of the extract) corresponded to purified trachelosperogenin $E$ (5); fraction $\mathbf{F}_{7}(11.4 \mathrm{mg}, 0.4 \% \mathrm{w} / \mathrm{w}$ of the extract) was approximately $1 / 3$ (based on ${ }^{1} \mathrm{H}$ NMR signal integration) mixture of trachelosperogenin $E(5)$ and catechin (6); fraction $\mathbf{F}_{25}$ corresponded to water-soluble 
tannins and sugars $\left(2071.9 \mathrm{mg}, 72.8 \% \mathrm{w} / \mathrm{w}\right.$ of the extract). The sample $\mathbf{F}_{0}$ corresponded to the crude extract without water soluble sugars and tannins (CBEWT) obtained after partitioning in the $\mathrm{MtBE} / \mathrm{CH}_{3} \mathrm{CN} / \mathrm{H}_{2} \mathrm{O}(4 / 1 / 5$, v/v) biphasic solvent system. Metabolites 1 to 6 were identified thanks to ${ }^{1} \mathrm{H}$ and ${ }^{13} \mathrm{C}$ NMR spectral data (see 1S Table). Their molecular structures were validated by further 2D NMR analyses (HSQC, HMBC and COSY) and by comparison with reference NMR data from the literature [15,16]. Their chemical structures are given in Fig 1.

DMSO was able to solubilize all samples, hence it was selected to test all of them (crude bark extract, $\mathbf{F}_{0}, \mathbf{F}_{5}, \mathbf{F}_{7}, \mathbf{F}_{11}, \mathbf{F}_{13}, \mathbf{F}_{18}$ and $\mathbf{F}_{25}$ ) [17].

The cytotoxicity of the crude bark extract, $\mathbf{F}_{\mathbf{0}}, \mathbf{F}_{\mathbf{5}}, \mathbf{F}_{\mathbf{7}}, \mathbf{F}_{\mathbf{1 1}}, \mathbf{F}_{\mathbf{1 3}}, \mathbf{F}_{\mathbf{1 8}}$ and $\mathbf{F}_{\mathbf{2 5}}$, was assessed on Vero cells which have significant advantages such as yield and viability for $T$. gondii culture (Table II). The $20 \%$ cytotoxic concentration $\left(\mathrm{CC}_{20}\right)$ values ranged from 7.27 to $85.62 \mu \mathrm{g} / \mathrm{mL}$ and corresponded to the acceptable limit of cell viability. Moreover, the values of $50 \%$ cytotoxic concentration $\left(\mathrm{CC}_{50}\right)$ ranged from 38.57 to more than 200 $\mu \mathrm{g} / \mathrm{mL}$. These results were confirmed microscopically after coloration with the RAL 555 kit. A concentration of $200 \mu \mathrm{g} / \mathrm{mL}$ of the crude bark extract was the most cytotoxic concentration for Vero cells, without inducing a complete cell death (see 2S Fig). Moreover, the fraction $\mathbf{F}_{5}$ containing 3,3'-di-O-methylellagic acid (6) and 3,4,3'-tri-Omethylflavellagic acid (5) was still very cytotoxic at $20 \mu \mathrm{g} / \mathrm{mL}$ and $40 \mu \mathrm{g} / \mathrm{mL}$. Lower concentrations showed no cytotoxicity. These two compounds were previously reported as cytotoxic agents against human cells [18]. Nevertheless these data could be useful for other studies focusing on the antiparasitic activity of A. leiocarpa metabolites on another intracellular parasite that can also invade Vero cells.

The crude bark extract of $A$. leiocarpa was tested for its potential antitoxoplasmic activity. Selectivity index (SI) was calculated for each tested sample (Table II). The ethanol crude bark extract of $A$. leiocarpa was effective with an $I_{50}$ of $59.30 \pm 9.16$ $\mu \mathrm{g} / \mathrm{mL}$ (Fig 2A) with a low selectivity index (SI 2.32), confirming that the African birch contains efficient molecules against protozoan parasites as previously described [11]. Remarkably this $\mathrm{IC}_{50}$ was in the same order of magnitude of the $\mathrm{IC}_{50}$ of sulfadiazine, which is $77 \mu \mathrm{g} / \mathrm{mL}(307.66 \mu \mathrm{M})$ [6], even though sulfadiazine is generally combined to other active molecules when used as an antitoxoplasmic treatment. This is interesting since there are very few treatments currently available against $T$. gondii. Seven chemically simplified fractions or purified compounds obtained after CPC fractionation of the crude extract were thus tested in order to understand which compound induced 
this antitoxoplasmic activity. Tannins $\left(\mathbf{F}_{\mathbf{2 5}}\right)$ and sericoside $\left(\mathbf{F}_{\mathbf{1 8}}\right)$ showed no antitoxoplasmic effect (Table II), that is consistent with previous results obtained on $P$. falciparum $[19,20]$. The crude bark extract without tannins $\left(\mathbf{F}_{0}\right)$ showed a lower average $\mathrm{IC}_{50}$ of $12.83 \pm 1.85 \mu \mathrm{g} / \mathrm{mL}$ (Fig 2B) with an increased selectivity index (SI 9.61). Ellagic acid $\left(\mathbf{F}_{13}\right)$ showed a low antitoxoplasmic activity, with an $\mathrm{IC}_{50}$ value of $74.06 \pm 19.60$ $\mu \mathrm{g} / \mathrm{mL}(245.08 \pm 64.68 \mu \mathrm{M})$. This result may seem surprising insofar as it is very active against $P$. falciparum [21]. The mixture of 3,3'-di-O-methylellagic acid and 3,4,3'-tri-Omethylflavellagic acid $\left(\mathbf{F}_{5}\right)$ showed an antitoxoplasmic activity, despite its cytotoxicity, with an $\mathrm{IC}_{50}$ value of $13.78 \pm 3.52 \mu \mathrm{g} / \mathrm{mL}$ but with a low selectivity index SI of 2.80. On the contrary, interestingly, trachelosperogenin $E\left(\mathbf{F}_{11}\right)$ showed an average $\mathrm{IC}_{50}$ of 26.63 $\pm 0.94 \mu \mathrm{g} / \mathrm{mL}(51.14 \pm 1.81 \mu \mathrm{M})$, with a selectivity index of 9.75 (higher than 5 ) and parasites were not detected at $100 \mu \mathrm{g} / \mathrm{mL}$ (Fig 2C). Trachelosperogenin E (5) could explain, at least in part, the antitoxoplasmic activity of $A$. leiocarpa. Finally, a mixture containing mainly catechin with a small amount of trachelosperogenin $E\left(\mathbf{F}_{7}\right)$ showed no activity against $T$. gondii. Consistently, catechin was previously reported to have no activity on $P$. falciparum [22] and as trachelosperogenin $E$ being the minor compound of this mixture (about 30\%), its concentration may not be enough to induce any antiparasitic effect. The $\mathrm{IC}_{50}$ of the reference drug, pyrimethamine, was measured at $0.29 \pm 0.19 \mu \mathrm{g} / \mathrm{mL}(1.20 \pm 0.79 \mu \mathrm{M})$ (Table II) for the T. gondii RH strain. These results were visually confirmed by fixation of the cultures with cold methanol and coloration with the kit RAL 555 for microscopic analyses (see 3S Fig).

Since the crude bark extract without tannins $\left(\mathbf{F}_{\mathbf{0}}\right)$ and trachelosperogenin $E\left(\mathbf{F}_{11}\right)$ were the most active with the most satisfying Sls (9.61 and 9.75, respectively), their mechanism of action was investigated during the cell invasion by $\mathrm{RH}$ strain tachyzoites before invading Vero cells. The used concentrations for the cell invasion assay were $20 \mu \mathrm{g} / \mathrm{mL}$ for $\boldsymbol{F}_{\mathbf{0}}$ and $30 \mu \mathrm{g} / \mathrm{mL}(57.61 \mu \mathrm{M})$ for $\mathbf{F}_{11}$. Results showed a significant inhibition of the invasion process, with $24 \%$ inhibition for CBEWT $\left(\mathbf{F}_{0}\right)$ and $56 \%$ inhibition for trachelosperogenin $E\left(F_{11}\right)$ (Fig 3). As expected, pyrimethamine showed no effect on T. gondii invasion (Fig 3). These results were also confirmed microscopically. Considering their respective efficiency against invasion, it appeared that most of the $\mathbf{F}_{0}$ and trachelosperogenin $E\left(F_{11}\right)$ activity took place during this process. The highest activity against cell invasion by $T$. gondii was indeed due to trachelosperogenin E, whereas CBEWT had a weak effect against it. Regarding its 
global activity on $T$. gondii growth, several active molecules should be contained in this extract and could also alter other processes such as parasite multiplication.

Considering these promising results, the in vivo antitoxoplasmic activity of the crude bark extract without tannin $\left(\mathbf{F}_{0}\right)$ and trachelosperogenin $E\left(\mathbf{F}_{11}\right)$ was also assessed. Mice were infected with ME49 strain tachyzoites. DMSO-treated group showed no significant difference in tachyzoites growth compared to untreated infected mice (control group). Only the crude bark extract without tannin provided a protection against brain invasion by $T$. gondii in our chronic toxoplasmosis model. Moreover, CBEWT had a significant activity against the parasite compared to trachelosperogenin $E$ at $J_{0}$ by increasing mice survival by $50 \%(p<0.05)$ and at $J_{3}$ compared to control group $(p<$ 0.05). Even if it was not significant, it also increased mice survival rate by $30 \%$ at $J_{+1}$. Nevertheless, a prophylaxis treatment $\left(J_{-1}\right)$ had no effect on the parasite load (Fig 4). It was also observed that CBEWT was able to significantly inhibit $T$. gondii growth in a chronic toxoplasmosis model $(p<0.05)$ (Fig 5$)$.

Finally, trachelosperogenin $E$ showed no significant antitoxoplasmic activity in our chronic toxoplasmosis mouse model (Fig 4). Even though CBEWT tended to be more efficient against toxoplasmosis compared to untreated mice at $J_{0}$ and $\mathrm{J}_{1}$, more animals would be required to highlight a significant difference between CBEWT and untreated control group.

In this study, we investigated both the in vitro and in vivo activity of several extracts, fractions and pure compounds from A. leiocarpa bark on $T$. gondii. For the first time, we highlighted that the crude bark extract without tannins and trachelosperogenin $\mathrm{E}$ (5) showed a promising in vitro antitoxoplasmic activity. More specifically trachelosperogenin $E$ was able to inhibit host cells invasion by $T$. gondii tachyzoites. However, molecular analyses should be considered to accurately understand the mechanism of action of $A$. leiocarpa metabolites on $T$. gondii. We also proved that the crude bark extract without tannins had an interesting antiparasitic activity in our chronic toxoplasmosis murine model. In order to enrich our results, it would be interesting to test the active compounds (CBEWT and trachelosperogenin E) on different toxoplasmosis murine models and/or in combination with a classical treatment such as sulfadiazine or pyrimethamine.

\section{Materials and Methods}




\section{Chemicals and plant materials}

Methyl-tert-butyl ether (MtBE), $n$-heptane, and acetonitrile $\left(\mathrm{CH}_{3} \mathrm{CN}\right)$, dimethylsulfoxide (DMSO) were purchased from Carlo Erba Reactifs SDS.

The ethanol (99\%) bark extract of $A$. leiocarpa was kindly provided by the company Givaudan (Active Beauty Department, Givaudan France).

\section{Apparatus and operation conditions}

Separation were accomplished by Centrifugal Partition Chromatography (CPC) on a column with a capacity of $303.5 \mathrm{~mL}$ (FCPE300®, Rousselet-Robatel-Kromaton) containing seven partition disks engraved with 231 twin partition cells $(\approx 1 \mathrm{~mL}$ per twin cell). The CPC column was filled with the lower phase at a minimal rotation speed of $200 \mathrm{rpm}$. The rotation speed was then increased up to $1200 \mathrm{rpm}$. The sample solution was loaded into the column by progressively pumping the less polar upper phase (first mobile phase) from 0 to $20 \mathrm{~mL} / \mathrm{min}$ in 3 minutes in the ascending mode (KNAUER Preparative Pump $1800 \AA$ V7115). The upper phase was pumped for 50 minutes to ensure the elution of all hydrophobic compounds. The moderately polar middle phase (second mobile phase) was then pumped for 33 minutes to elute compounds with a medium polarity. Finally, the column was extruded to recover the most hydrophilic compounds retained inside the column (tannins). Fractions of $20 \mathrm{~mL}$ were collected over the whole experiment using a Pharmacia Superfrac collector. The separation was monitored by UV at 210, 254, 280 and $366 \mathrm{~nm}$ (UVD 170S detector, Dionex).

All CPC fractions were checked by Thin Layer Chromatography (TLC) on Merck 60 F254 pre-coated silica gel plates and developed with ethyl acetate / toluene / acetic acid / formic acid (70:30:11:11 v/v). UV light was used to detect ellagic acid and its derivatives at 254 and $365 \mathrm{~nm}$. TLC plates were then sprayed with a vanillin $(5 \% \mathrm{w} / \mathrm{v}$ in $\mathrm{EtOH}$ ) and $\mathrm{H}_{2} \mathrm{SO}_{4}$ solution ( $50 \% \mathrm{v} / \mathrm{v}$ in $\mathrm{MeOH}$ ), followed by heating at $100-120^{\circ} \mathrm{C}$ for 2-3 min. About $20 \mathrm{mg}$ of each sub-fraction were dissolved in $600 \mu \mathrm{L} \mathrm{DMSO}-d 6$ and analyzed by nuclear magnetic resonance (NMR) spectroscopy at $298 \mathrm{~K}$ on a Bruker Avance AVIII-600 spectrometer. ${ }^{1} \mathrm{H}$ and ${ }^{13} \mathrm{C}$ NMR spectra were acquired at $600.15 \mathrm{MHz}$ and $150.91 \mathrm{MHz}$, respectively. Additional heteronuclear single quantum coherence (HSQC), heteronuclear multiple bound correlation (HMBC), and homonuclear correlation spectroscopy (COSY) 2D-NMR experiments were performed 
on fractions containing putatively identified compounds using standard Bruker microprograms.

\section{Crude extract fractionation}

First of all, $504 \mathrm{mg}$ of the crude bark extract of Anogeissus leiocarpa were partitioned in $10 \mathrm{~mL}$ of a biphasic solvent system composed of $\mathrm{MtBE}, \mathrm{CH}_{3} \mathrm{CN}$ and $\mathrm{H}_{2} \mathrm{O}$ in the proportions 4/1/5 (v/v) in order to separate the highly abundant sugars and watersoluble tannins from the other potentially active secondary metabolites of lower polarity (triterpenes, methylated ellagic acid derivatives, flavonoids and saponins). The upper phase was recovered and evaporated to dryness, resulting in a residue of $141 \mathrm{mg}$ ( $28 \%$ of the crude extract mass). This residue, corresponding to the crude bark extract without tannins, was annotated CBEWT and corresponded to sample $\mathbf{F}_{\mathbf{0}}$.

In parallel, the crude bark extract of $A$. leiocarpa was also fractioned by CPC using method previously fully described [12]. Briefly, a three-phase solvent system was prepared by mixing $n$-heptane $(700 \mathrm{~mL}), \mathrm{MtBE}(700 \mathrm{~mL}), \mathrm{CH}_{3} \mathrm{CN}(700 \mathrm{~mL})$ and water $(700 \mathrm{~mL})$ in a separatory funnel. After separation of the $n$-heptane rich upper phase, $700 \mathrm{~mL}$ of MtBE were added to the mixture of middle and lower phases in order to slightly reduce the polarity of the remaining two-phase solvent system. For the injection step, $3 \mathrm{~g}$ of the crude bark extract of $A$. leiocarpa were dissolved in a mixture of lower phase / middle phase / upper phase (45:10:5 v/v) and the $\mathrm{pH}$ was adjusted to 4-5 with sodium hydroxide. All CPC fractions were combined on the basis of TLC composition similarities, resulting in a series of 25 sub-fractions or purified compounds (Table I).

\section{NMR analyses of the CPC fractions}

On the basis of NMR spectral profiles, six fractions exhibiting a chemical composition representative of the main molecular classes present in the crude bark extract of $A$. leiocarpa were selected to perform the in vitro antitoxoplasmic assays. These selected fractions were $\mathbf{F}_{5}$ (3,3'-di-O-methylellagic acid + 3,4,3'-tri-O-methylflavellagic acid), $\mathbf{F}_{7}$ (trachelosperogenin E + catechin), $\mathbf{F}_{11}$ (trachelosperogenin E), $\mathbf{F}_{13}$ (ellagic acid), $\mathbf{F}_{\mathbf{1 8}}$ (sericoside) and $\mathbf{F}_{25}$ (water-soluble tannins) (Table I). Residual solvent percentages were not evaluated prior to experiments since solvents were evaporated after the extraction of the natural compounds. 


\section{T. gondii strains}

$\mathrm{RH}$ (type I) and ME49 (type II) strains of $T$. gondii were provided by the French Biological Toxoplasma Resource Centre (Biological resource center Toxoplasma, France).

\section{Parasites growth}

$\mathrm{RH}$ and ME49 strains tachyzoites were cultured on Vero cell monolayers (American Type Culture Collection (ATCC), CCL-81) at $37^{\circ} \mathrm{C}, 5 \% \mathrm{CO}_{2}$ in a humidified incubator. Both cells and parasites were grown in complete medium Iscove's Modified Dulbecco's Medium/Glutamax (IMDM) (Invitrogen) supplemented with $2 \%(\mathrm{v} / \mathrm{v})$ fetal calf serum (Biowest) and antibiotics (100 IU/mL penicillin and $0.1 \mathrm{mg} / \mathrm{mL}$ streptomycin) (GIBCO). Host cells were infected at a 1:1 parasite to cell ratio. Cells and tachyzoites were counted using a Kova Slide counting chamber with Trypan blue (v/v).

\section{In vitro chemosensitivity of $T$. gondii and cytotoxicity evaluation}

The in vitro chemosensitivity of $T$. gondii $\left(\mathrm{IC}_{50}\right)$ was assessed as previously described [6]. The crude bark extract, the crude bark extract without tannins $\left(\mathbf{F}_{0}\right), \mathbf{F}_{5}, \mathbf{F}_{7}, \mathbf{F}_{11}, \mathbf{F}_{13}$, $\mathbf{F}_{18}$ and $\mathbf{F}_{25}$ were tested at ten concentrations obtained by twofold dilution series from a stock solution (crude bark extract and samples $\mathbf{F}_{\mathbf{0}}, \mathbf{F}_{\mathbf{7}}, \mathbf{F}_{\mathbf{1 1}}, \mathbf{F}_{\mathbf{1 3}}, \mathbf{F}_{\mathbf{1 8}}$ and $\mathbf{F}_{25}$ : 0.39 to $200 \mu \mathrm{g} / \mathrm{mL} ; \mathbf{F}_{5}: 0.078$ to $40 \mu \mathrm{g} / \mathrm{mL}$ ) for 72 hours. Pyrimethamine (Pyr) was used as a positive control. T. gondii growth was determined by an enzyme-linked immunosorbent assay (ELISA) on the fixed infected cultures with an anti- $T$. gondii surface antigen-1horseradish peroxidase (SAG-1-HRP) conjugated monoclonal antibody (Argene Biosoft). Spectrophotometric readings (FLUOstar Omega microplate reader, BMG Labtech) were made at $450 \mathrm{~nm}$, corrected at $630 \mathrm{~nm}$. For a visual control, the last well of each condition was fixed with cold methanol, stained with kit RAL 555 (RAL Diagnostics) and examined microscopically (AxioVert $200 \mathrm{M}$, Zeiss) at magnification 20x.

The in vitro cytotoxicity $\left(\mathrm{CC}_{20}\right.$ and $\left.\mathrm{CC}_{50}\right)$ of samples was evaluated on Vero cell cultures using the UptiBlue viable cell counting assay (Interchim): wells were emptied and washed with cold Phosphate Buffered Saline (PBS) (Sigma-Aldrich). Then, 100 $\mu \mathrm{L}$ of IMDM supplemented with $2 \%(\mathrm{v} / \mathrm{v})$ fetal calf serum and $10 \%(\mathrm{v} / \mathrm{v})$ UptiBlue were added in each well. Afterwards plates were incubated at $37^{\circ} \mathrm{C}$ for 3 hours. The protocol 
was slightly the same as described above, except that no parasite was inoculated in wells. Spectrophotometric readings (FLUOstar Omega microplate reader, BMG Labtech) were made at $570 \mathrm{~nm}$, corrected at $600 \mathrm{~nm}$. Visual control was made as described above.

\section{$\mathrm{IC}_{50}$ data analysis}

The effect of the crude extract and fractions at various concentrations was determined by data plotting as previously described [23] with minor modifications to the $y$ axis. Results were averaged, optical densities (OD) values for cultures without drug treatment were used at $100 \%$ value of parasites growth and plotted as a function of the logarithm of each compound concentration. The $\mathrm{IC}_{50}$ value was calculated as the sample concentration for which $50 \%$ of parasite growth was inhibited.

\section{Selectivity indexes}

A selectivity index (SI) was calculated for each sample, as the ratio between cytotoxic and antiparasitic activities:

SI Toxoplasma $=\mathrm{CC}_{50}$ Vero $/ \mathrm{IC}_{50}$ Toxoplasma $\mathrm{RH}$

The antitoxoplasmic effect was considered selective if $\mathrm{SI}>5$. This cut-off point was based on previous studies focused on anti-Toxoplasma activities in which SIs had to be $>4$ [24] or 6 [25] to be considered selective.

\section{Invasion assay}

In order to determine which part of $T$. gondii life cycle was inhibited by the most selective compounds, an invasion assay was performed for each compound. A previously described protocol was adapted to our model [26]. Briefly, in a 96-well plate, 40,000 Vero cells were incubated for four hours at $37^{\circ} \mathrm{C}$ and $5 \% \mathrm{CO}_{2}$. The wells containing Vero cells were then emptied and refilled with 100,000 tachyzoites (RH strain) preincubated for 20 minutes with active compound or pyrimethamine at room temperature in $100 \mu \mathrm{L}$ of parasite/active compound suspension per well, except for eight wells as negative control. Eight other wells were refilled with 100,000 tachyzoites without active compound and were used as invasion positive control. The plate was incubated for one hour as described above and wells were washed with phosphate buffered saline (PBS). The plate was then fixed with cold methanol as described 
previously and rehydrated with $100 \mu \mathrm{L}$ of PBS per well for 10 minutes. Wells were emptied again before adding the anti-T. gondii SAG-1-HRP conjugated monoclonal antibody (Argene Biosoft) and incubated at $37^{\circ} \mathrm{C}$ for one hour. They were then emptied and washed before adding an anti-mouse antibody coupled with AlexaFluor 488 and incubated for one hour at room temperature. Spectrofluorimetric readings (FLUOstar Omega microplate reader, BMG Labtech) were made at $490 \mathrm{~nm}$ and blank readings were made on the mean value of the eight negative control wells. Microscopic analysis were performed at magnification 40x (AxioVert 200M, Zeiss).

\section{In vivo chemosensitivity of $T$. gondii}

The in vivo experimentations were approved by the Comité d'Ethique en Experimentation Animale de Reims Champagne-Ardenne (C2EA 56) on July $17^{\text {th }}$, 2018, acceptation number APAFIS\#6851-2016092210116940v3.

The in vivo antitoxoplasmic activity of the in vitro active and selective compounds was assessed in 8-months old female Swiss mice, weighing 20 grams and provided by Charles River Laboratories. Immunocompetent mice were infected with $T$. gondii ME49 strain (type II) tachyzoites to mimic chronic toxoplasmosis. This strain was chosen due to the high predominance of genotype II strains in Europe [27]. The parasites inoculation and treatments injections were made intraperitoneally. A 1\% (v/v) DMSO injection was used as a negative control. In total 95 mice were used for the experiment. The group was divided into four subgroups, each of which was submitted to the following conditions:

I: control group $(n=5)$ : ME49 parasites, no treatment.

II: DMSO group $(n=10)$ : ME49 parasites, injection of $1 \%(v / v)$ DMSO 10 minutes after parasites infestation (JO).

III: CBEWT group ( $\mathrm{n}=10$ for each condition): ME49 parasites, injection of CBEWT $(200 \mu \mathrm{g} / \mathrm{mL}$ ) solubilized in 1\% (v/v) DMSO at J0, J+1 (24 hours after infestation), J+3 (72 hours after infestation) or $\mathrm{J}-1$ (24 hours before infestation).

IV: TrachE group ( $\mathrm{n}=10$ for each condition): ME49 parasites, injections of trachelosperogenin $\mathrm{E}(200 \mathrm{\mu g} / \mathrm{mL})$ solubilized in $1 \%(\mathrm{v} / \mathrm{v})$ DMSO at $\mathrm{J} 0, \mathrm{~J}+1, \mathrm{~J}+3$ or $\mathrm{J}$ 1. 
Surviving mice were sacrificed 30 days after tachyzoites infestation $(\mathrm{J}+30)$ and brains were collected. The samples were then analyzed by Real Time-qPCR to measure the parasite load as previously described $[28,29]$. If mice died before $\mathrm{J}+30$, the day of death was recorded $(\mathrm{J}+\mathrm{X})$. Data were analyzed as survival curves.

Mice were under constant survey during the experiment in order to avoid any suffering or distress induced by the parasite load or the treatments.

\section{Statistical analysis}

For $\mathrm{CC}_{50}$ and $\mathrm{IC}_{50}$ assays, values were expressed as mean \pm standard deviation. For the invasion assay results comparison, a one-way ANOVA test $(p<0.05)$ followed by a Holm-Hidak's multiple comparisons test were performed. The software used was GraphPad Prism 7.0.

For the in vivo active compounds, statistical analyses were performed using a nonparametric Kruskal-Wallis test followed by a post hoc nonparametric WilcoxonMann-Whitney test. P-values $<0.05$ were considered to be statistically significant.

\section{Supporting Information}

${ }^{13} \mathrm{C}$ NMR assignments of $A$. leiocarpa as well as cytotoxic activity of the crude bark extract and optical microscopic observation of the $\mathrm{RH}$ strain of $T$. gondii growth in presence of each compound/fraction from A. leiocarpa are available as Supporting Information.

\section{Acknowledgments}

We thank the URCA PICT platform for their assistance in imagery and microscopy controls. We thank the URCA PIAneT platform and Agathe Martinez for her assistance for NMR spectra recording. We are very grateful to the Champagne-Ardenne region and the Robert Debré University-affiliated Hospital of Reims, which funded the thesis subject that led to this study. We also thank Regine Geers, Emilie Josse-Dupuis and Loren Andrulewiez for their great technical help in this study. The "Société d'Accélération du Transfert de Technologie (SATT)" Nord is gratefully acknowledged for its financial support.

\section{Conflict of interest}


The authors declare no conflict of interest.

\section{References}

1 Deng Y, Wu T, Zhai S-Q, Li C-H. Recent progress on anti-Toxoplasma drugs discovery: Design, synthesis and screening. Eur J Med Chem 2019; 183: 111711

2 Weiss LM, Dubey JitenderP. Toxoplasmosis: a history of clinical observations. Int $\mathrm{J}$ Parasitol 2009; 39: 895-901

3 Howe DK, Sibley LD. Toxoplasma gondii comprises three clonal lineages: correlation of parasite genotype with human disease. J Infect Dis 1995; 172: 15611566

4 Baatz H, Mirshahi A, Puchta J, Gümbel H, Hattenbach L-O. Reactivation of Toxoplasma retinochoroiditis under atovaquone therapy in an immunocompetent patient. Ocul Immunol Inflamm 2006; 14: 185-187

6 Doliwa C, Escotte-Binet S, Aubert D, Velard F, Schmid A, Geers R, Villena I. Induction of sulfadiazine resistance in vitro in Toxoplasma gondii. Exp Parasitol 2013; 133: 131-136

7 Meneceur P, Bouldouyre M-A, Aubert D, Villena I, Menotti J, Sauvage V, Garin J-F, Derouin $\mathrm{F}$. In vitro susceptibility of various genotypic strains of Toxoplasma gondii to pyrimethamine, sulfadiazine, and atovaquone. Antimicrob Agents Chemother 2008; 52: $1269-1277$

8 Mann A, Gbate M, Nda Umar A. Medicinal and economic plants of Nupeland. Bida, Nigeria: Jube Evans Books and Publications, 2003

9 Adamu HM, Abayeh OJ, Agho MO, Abdullahi AL, Uba A, Dukku HU, Wufem BM. An ethnobotanical survey of Bauchi State herbal plants and their antimicrobial activity. J Ethnopharmacol 2005; 99: 1-4

10 Gansané A, Sanon S, Ouattara LP, Traoré A, Hutter S, Ollivier E, Azas N, Traore AS, Guissou IP, Sirima SB, Nebié I. Antiplasmodial activity and toxicity of crude extracts from alternatives parts of plants widely used for the treatment of malaria in Burkina Faso: contribution for their preservation. Parasitol Res 2010; 106: 335-340

11 Okpekon T, Yolou S, Gleye C, Roblot F, Loiseau P, Bories C, Grellier P, Frappier F, Laurens A, Hocquemiller R. Antiparasitic activities of medicinal plants used in Ivory Coast. J Ethnopharmacol 2004; 90: 91-97

12 Hamzaoui M, Renault J-H, Nuzillard J-M, Reynaud R, Hubert J. Stepwise elution of a three-phase solvent system in centrifugal partition extraction: a new strategy for the fractionation and phytochemical screening of a crude bark extract. Phytochem Anal PCA 2013; 24: 367-373

${ }^{13}$ Hubert J, Nuzillard J-M, Purson S, Hamzaoui M, Borie N, Reynaud R, Renault J-H. Identification of natural metabolites in mixture: a pattern recognition strategy based on (13)C NMR. Anal Chem 2014; 86: 2955-2962 
${ }^{14}$ Berthod A, Ruiz-Angel MJ, Carda-Broch S. Elution-extrusion countercurrent chromatography. Use of the liquid nature of the stationary phase to extend the hydrophobicity window. Anal Chem 2003; 75: 5886-5894

${ }^{15}$ Sato T. Spectral differentiation of 3,3'-di-O-methylellagic acid from 4,4'-di-Omethylellagic acid. Phytochemistry 1987; 26: 2124-2125

${ }^{16}$ Serafin C, Nart V, Malheiros A, de Souza MM, Fischer L, Delle Monache G, Della Monache F, Cechinel Filho V. Bioactive phenolic compounds from aerial parts of Plinia glomerata. Z Naturforschung C J Biosci 2007; 62: 196-200

17 Kelava T, Ćavar I, Čulo F. Biological actions of drug solvents. Period Biol 2011; 113 : 311-320

${ }^{18}$ Kuete V, Dongmo Mafodong FL, Celik I, Fobofou SAT, Ndontsa BL, Karaosmanoğlu $\mathrm{O}$, Weissjohann LA, Tane P, Koparal AT, Sivas H. In vitro cytotoxicity of compounds isolated from Desbordesia glaucescens against human carcinoma cell lines. South Afr J Bot 2017; 111: 37-43

${ }^{19}$ Asres K, Bucar F, Knauder E, Yardley V, Kendrick H, Croft SL. In vitro antiprotozoal activity of extract and compounds from the stem bark of Combretum molle. Phytother Res PTR 2001; 15: 613-617

20 Kumulungui SB, Ondo-azi SA, Mewono L, Otogo N'nang E, Akagah B, Fumoux F, Traoré A. In vitro behaviour of Plasmodium falciparum strains by alkaloids and tannins extracted from root of Mitragyna inermis, a medicinal plant. Int J Curr Pharm Res 2015; $\quad 7 \quad$ Im Internet: http://innovareacademics.in/journals/index.php/ijcpr/article/view/6300

${ }^{21}$ Soh PN, Witkowski B, Olagnier D, Nicolau M-L, Garcia-Alvarez M-C, Berry A, Benoit-Vical $\mathrm{F}$. In vitro and in vivo properties of ellagic acid in malaria treatment. Antimicrob Agents Chemother 2009; 53: 1100-1106

22 Tasdemir D, Lack G, Brun R, Rüedi P, Scapozza L, Perozzo R. Inhibition of Plasmodium falciparum fatty acid biosynthesis: evaluation of FabG, FabZ, and Fabl as drug targets for flavonoids. J Med Chem 2006; 49: 3345-3353

${ }^{23}$ Derouin F, Chastang C. In vitro effects of folate inhibitors on Toxoplasma gondii. Antimicrob Agents Chemother 1989; 33: 1753-1759

${ }^{24}$ Spalenka J, Escotte-Binet S, Bakiri A, Hubert J, Renault J-H, Velard F, Duchateau S, Aubert D, Huguenin A, Villena I. Discovery of New Inhibitors of Toxoplasma gondii via the Pathogen Box. Antimicrob Agents Chemother 2018; 62 Im Internet: https://www.ncbi.nlm.nih.gov/pmc/articles/PMC5786798/

${ }^{25}$ Boyom FF, Fokou PVT, Tchokouaha LRY, Spangenberg T, Mfopa AN, Kouipou RMT, Mbouna CJ, Donfack VFD, Zollo PHA. Repurposing the Open Access Malaria Box To Discover Potent Inhibitors of Toxoplasma gondii and Entamoeba histolytica. Antimicrob Agents Chemother 2014; 58: 5848-5854 
26 D’Angelo JG, Bordón C, Posner GH, Yolken R, Jones-Brando L. Artemisinin derivatives inhibit Toxoplasma gondii in vitro at multiple steps in the lytic cycle. $J$ Antimicrob Chemother 2009; 63: 146-150

${ }^{27}$ Robert-Gangneux F, Dardé M-L. Epidemiology of and Diagnostic Strategies for Toxoplasmosis. Clin Microbiol Rev 2012; 25: 264-296

${ }^{28}$ De Craeye S, Speybroeck N, Ajzenberg D, Dardé ML, Collinet F, Tavernier P, Van Gucht S, Dorny P, Dierick K. Toxoplasma gondii and Neospora caninum in wildlife: common parasites in Belgian foxes and Cervidae? Vet Parasitol 2011; 178: 64-69

${ }^{29}$ Meerburg BG, De Craeye S, Dierick K, Kijlstra A. Neospora caninum and Toxoplasma gondii in brain tissue of feral rodents and insectivores caught on farms in the Netherlands. Vet Parasitol 2012; 184: 317-320 
Table I: Mass repartition of the CPC fractions obtained from the ethanolic extract of Anogeissus leiocarpa.

\begin{tabular}{|c|c|c|c|}
\hline $\begin{array}{c}\text { CPC } \\
\text { fractions* }\end{array}$ & $\begin{array}{c}\text { Mass } \\
(\mathrm{mg})\end{array}$ & $\begin{array}{l}\% \text { of the total } \\
\text { extract mass }\end{array}$ & Composition \\
\hline $\mathrm{F}_{1}-\mathrm{F}_{4}$ & 264.1 & $9.3 \%$ & Complex metabolite mixture \\
\hline $\mathbf{F}_{5}$ & 15,7 & $0,6 \%$ & $\begin{array}{l}\text { 3,3'-di-O-methylellagic acid (3) + 3,4,3'- } \\
\text { tri-O-methylflavellagic acid (4) }\end{array}$ \\
\hline $\mathrm{F}_{6}$ & 14,3 & $0,5 \%$ & Complex metabolite mixture \\
\hline $\mathbf{F}_{7}$ & 11,4 & $0,4 \%$ & Trachelosperogenin E (5) + catechin (6) \\
\hline $\mathrm{F}_{8}-\mathrm{F}_{10}$ & 60.5 & $2.1 \%$ & Complex metabolite mixture \\
\hline $\mathbf{F}_{11}$ & 28 & $1,0 \%$ & Trachelosperogenin E (5) \\
\hline $\mathrm{F}_{12}$ & 19,5 & $0,7 \%$ & Complex metabolite mixture \\
\hline $\mathbf{F}_{13}$ & 22,8 & $0,8 \%$ & ellagic acid (2) \\
\hline $\mathrm{F}_{14}-\mathrm{F}_{17}$ & 114.2 & $4.1 \%$ & Complex metabolite mixture \\
\hline $\mathbf{F}_{18}$ & 35,2 & $1,2 \%$ & pure sericoside (1) \\
\hline $\mathrm{F}_{19}-\mathrm{F}_{24}$ & 189.7 & $6.8 \%$ & Complex metabolite mixture \\
\hline $\mathbf{F}_{25}$ & 2071,9 & $72,8 \%$ & Water-soluble tannins and sugars \\
\hline
\end{tabular}

${ }^{*}$ in bold, selected fractions for in vitro assays 
Table II. Cytotoxic and antitoxoplasmic activities of the eight samples obtained by CPC and pyrimethamine (Pyr). Values are expressed as 95\% confidence intervals. Underlined value is theoretical based on the trend line since $\mathrm{CC}_{50}$ was not reached.

\begin{tabular}{|c|c|c|c|c|}
\hline Compound & $\begin{array}{c}\mathrm{CC}_{50} \text { on } \\
\text { Vero cells } \\
(\mu \mathrm{g} / \mathrm{mL})\end{array}$ & $\begin{array}{c}\mathrm{CC}_{20} \text { on } \\
\text { Vero cells } \\
(\mu \mathrm{g} / \mathrm{mL})\end{array}$ & $\begin{array}{c}\mathrm{IC}_{50} \text { on } \mathrm{T} \text {. } \\
\text { gondii } \\
(\mu \mathrm{g} / \mathrm{mL})\end{array}$ & $\begin{array}{l}\text { Selectivity } \\
\text { index }\end{array}$ \\
\hline Crude bark extract & $\begin{array}{c}119.2- \\
156.0\end{array}$ & $19.3-44.5$ & $46.6-72.0$ & 2.3 \\
\hline $\begin{array}{l}\text { Crude bark extract } \\
\text { without tannin - CBEWT } \\
\left(\mathbf{F}_{0}\right)\end{array}$ & $\begin{array}{c}106.1- \\
140.5\end{array}$ & $5.3-9.2$ & $10.3-15.4$ & 9.6 \\
\hline Sericoside $\left(\mathbf{F}_{18}\right)$ & $>200$ & $74.7-89.3$ & $118.2-151.2$ & $<5$ \\
\hline Ellagic acid $\left(\mathbf{F}_{\mathbf{1 3}}\right)$ & $>200$ & $9.9-32.7$ & $46.9-101.2$ & $>2.7$ \\
\hline $\begin{array}{l}\text { Methylated ellagic acid } \\
\text { derivatives }\left(\mathbf{F}_{5}\right)\end{array}$ & $26.8-50.3$ & $3.6-13.1$ & $8.9-18.7$ & 2.8 \\
\hline $\begin{array}{l}\text { Trachelosperogenin } \mathrm{E} \\
\left(\mathbf{F}_{11}\right)\end{array}$ & $\underline{252.4-}$ & $11.2-13.6$ & $25.3-27.9$ & 9.7 \\
\hline $\begin{array}{l}\text { Trachelosperogenin E + } \\
\text { catechin }\left(\mathbf{F}_{\mathbf{7}}\right)\end{array}$ & $>200$ & $\begin{array}{c}58 . \\
2-113.0\end{array}$ & $135.6-169.5$ & $<5$ \\
\hline $\begin{array}{l}\text { Water-soluble tannins + } \\
\text { sugars }\left(\mathbf{F}_{25}\right)\end{array}$ & $>200$ & $36.4-55.8$ & $105.9-112.4$ & $<5$ \\
\hline Pyrimethamine (Pyr) & $2.1-3.0$ & $1.1-2.2$ & $0.0-0.5$ & 9.0 \\
\hline
\end{tabular}


<smiles>[R6]Oc1cc2c(=O)oc3c([R6])c([R6])c([R6])c4c(=O)oc(c1[R])c2c34</smiles>

$R_{1}=R_{2}=R_{3}=R_{4}=R_{5}=H$ : Ellagic acid (2)

$\mathrm{R}_{1}=\mathrm{R}_{2}=\mathrm{R}_{4}=\mathrm{H}, \mathrm{R}_{3}=\mathrm{R}_{5}=\mathrm{CH}_{3}: 3,3^{\prime}$-di-O-methylellagic acid (3)

$\mathrm{R}_{1}=\mathrm{OH}, \mathrm{R}_{2}=\mathrm{R}_{3}=\mathrm{R}_{5}=\mathrm{CH}_{3}, \mathrm{R}_{4}=\mathrm{H}, 3,4,3^{\prime}$-tri-O-methylflavellagic acid (4)

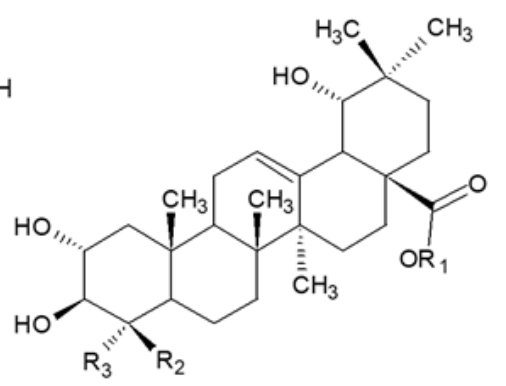

$\mathrm{R}_{1}=$ glucose, $\mathrm{R}_{2}=\mathrm{CH}_{3}, \mathrm{R}_{3}=\mathrm{CH}_{2} \mathrm{OH}$ : Sericoside (1) $\mathrm{R}_{1}=\mathrm{H}, \mathrm{R}_{2}=\mathrm{R}_{3}=\mathrm{CH}_{2} \mathrm{OH}$ : Trachelosperogenin E (5)

Figure 1: Chemical structures of the main metabolites recovered from the crude bark extract of Anogeissus leiocarpa and selected for biological evaluation against Toxoplasma gondii. 

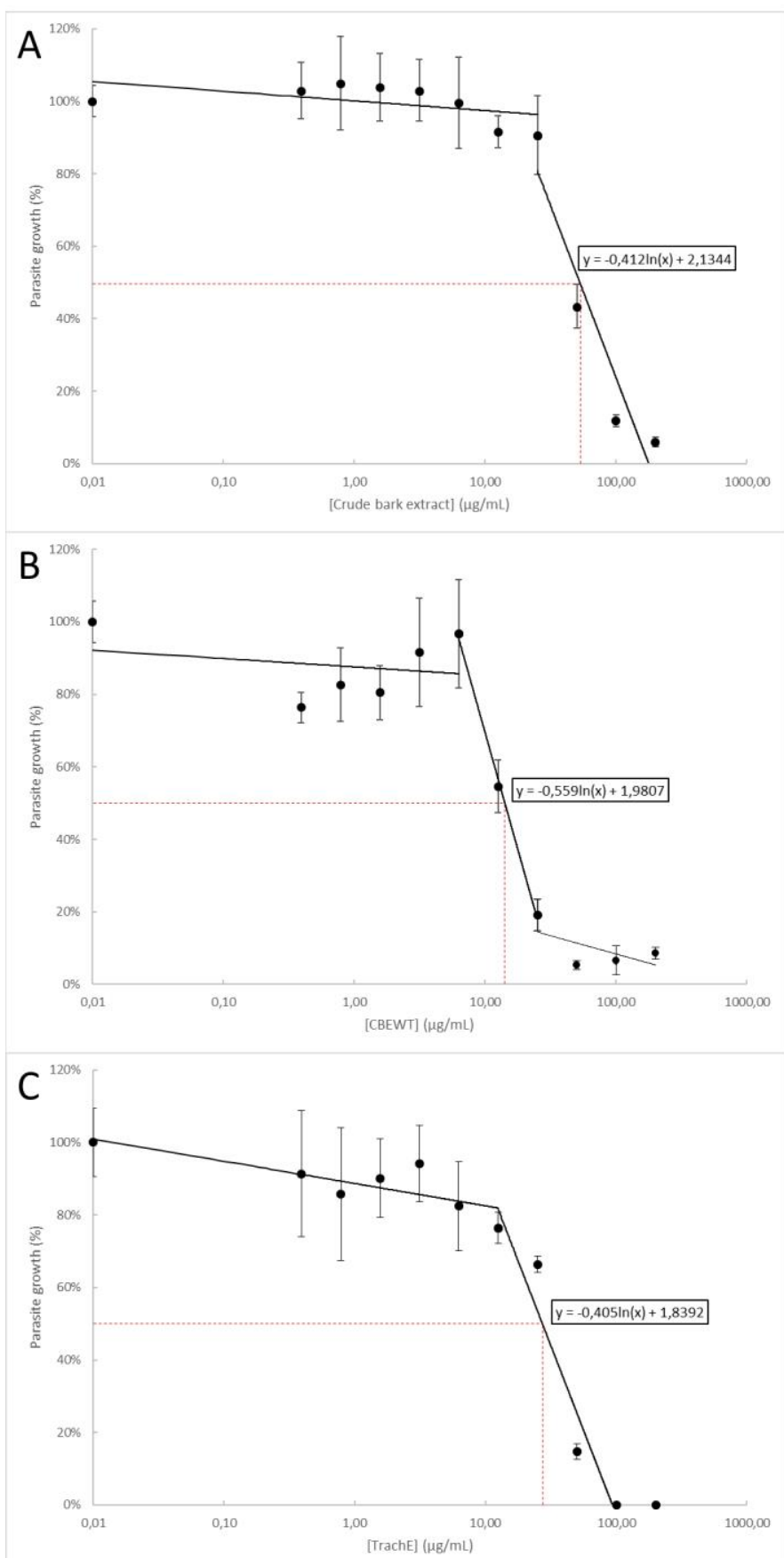

Figure 2: Representative dose-response curves of the in vitro effect of crude bark extract $(\mathrm{A}), \mathbf{F}_{\mathbf{0}}(\mathrm{B})$ and $\mathbf{F}_{\mathbf{1 1}}(\mathrm{C})$ from $A$. leiocarpa on $T$. gondii $\mathrm{RH}$ strain growth after 72 $\mathrm{h}$ of incubation ( $\mathrm{n}=$ three replicates). Each graph shows the tachyzoites growth compared to a positive control and determined by ELISA with infected monolayers ( $y$ axis) versus compound concentration ( $x$ axis). Values are expressed as mean \pm SD. 


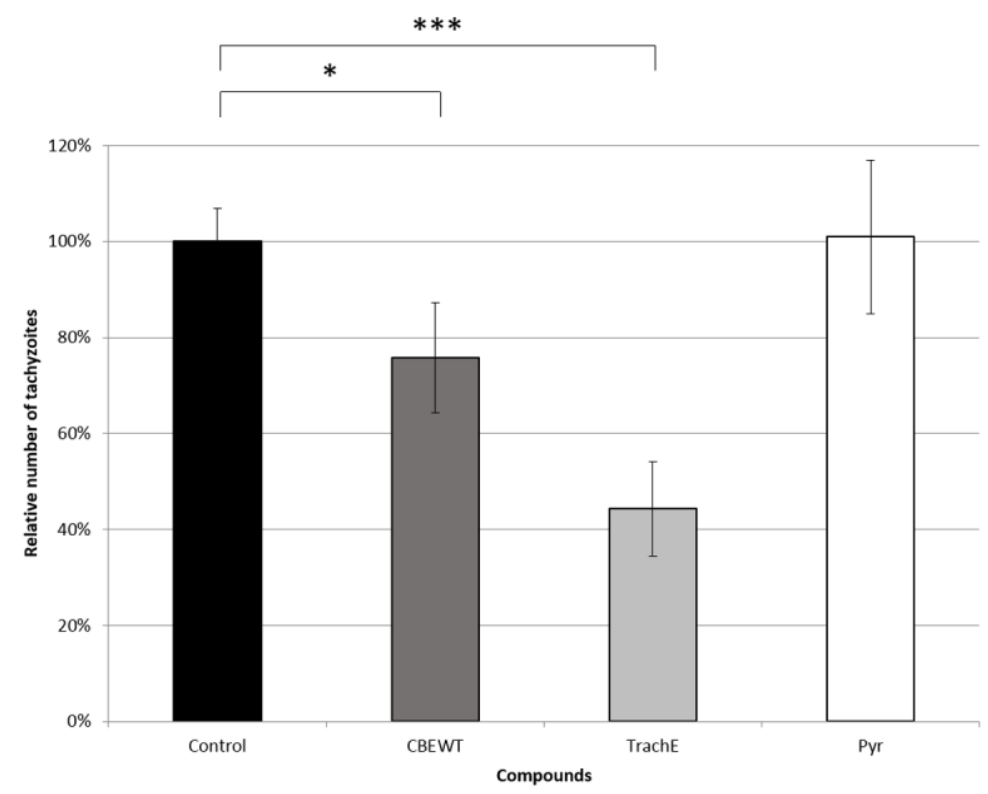

Figure 3: Relative number of parasites after incubation of tachyzoites with crude bark extract without tannin (CBEWT), trachelosperogenin E (TrachE) or pyrimethamine (Pyr). This experiment reflects the inhibition of the cell invasion by T. gondii tachyzoites induced by the natural compounds that showed an in vitro activity. ${ }^{*} p<0.05,{ }^{* * *} p<$ 0.007 compared to the control group ( $n=$ three replicates). 

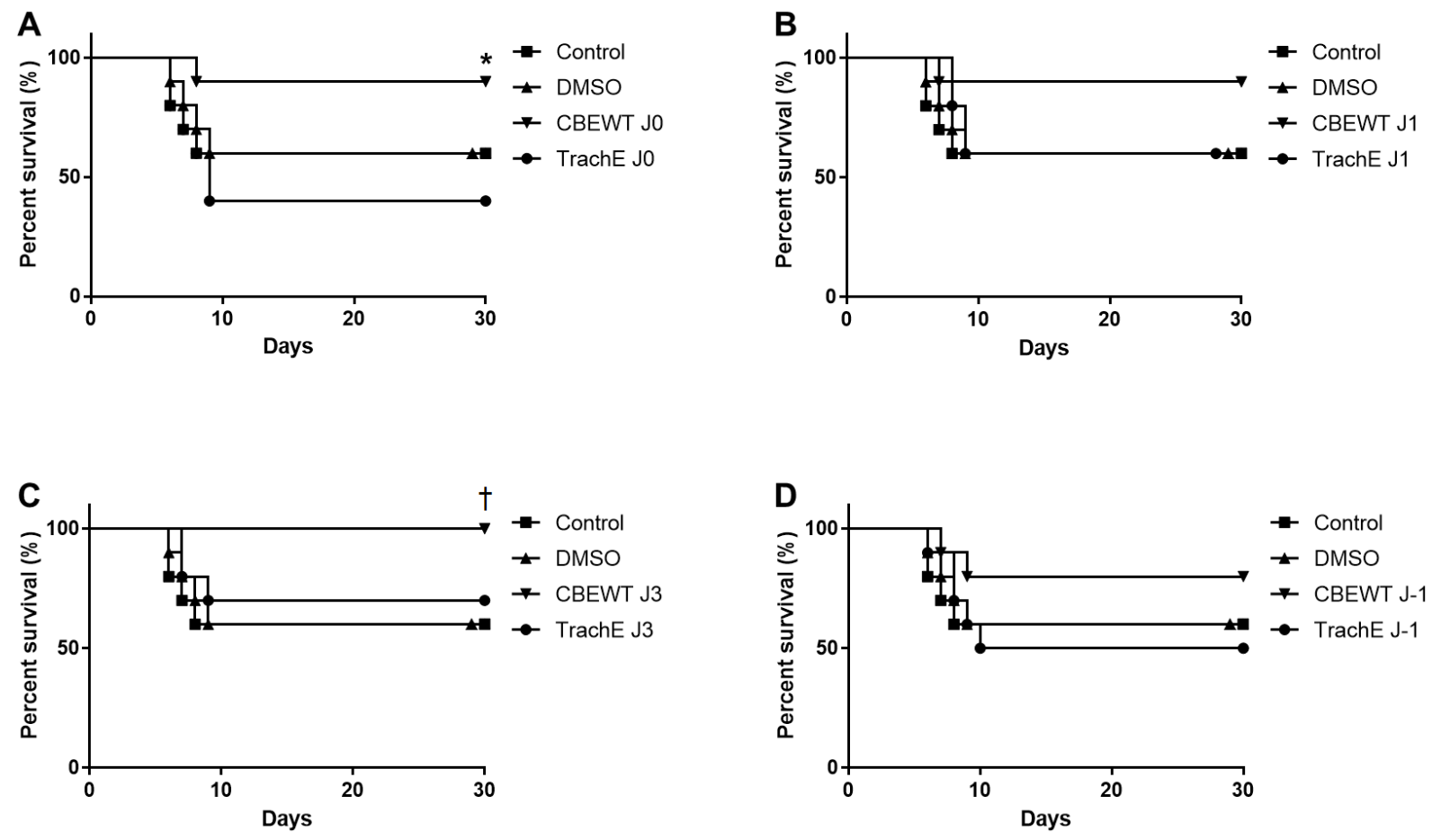

Figure 4: Antitoxoplasmic activity of the crude bark extract without tannins (CBEWT) and trachelosperogenin $\mathrm{E}$ (TrachE) in our chronic toxoplasmosis mouse model induced by ME49 strain tachyzoites. Treatments were intraperitoneally injected at $J_{0}$ (A), $\mathrm{J}_{+1}(\mathrm{~B}), \mathrm{J}_{+3}(\mathrm{C})$ and $\mathrm{J}_{-1}(\mathrm{D})$. Control consisted in infected mice without treatment. DMSO consisted in $1 \%(\mathrm{v} / \mathrm{v})$ DMSO injected in infected mice as a negative control ( ${ }^{*} \mathrm{p}$ $<0.05$ compared to TrachE-treated group; ${ }^{\dagger} p<0.05$ compared to control group). 


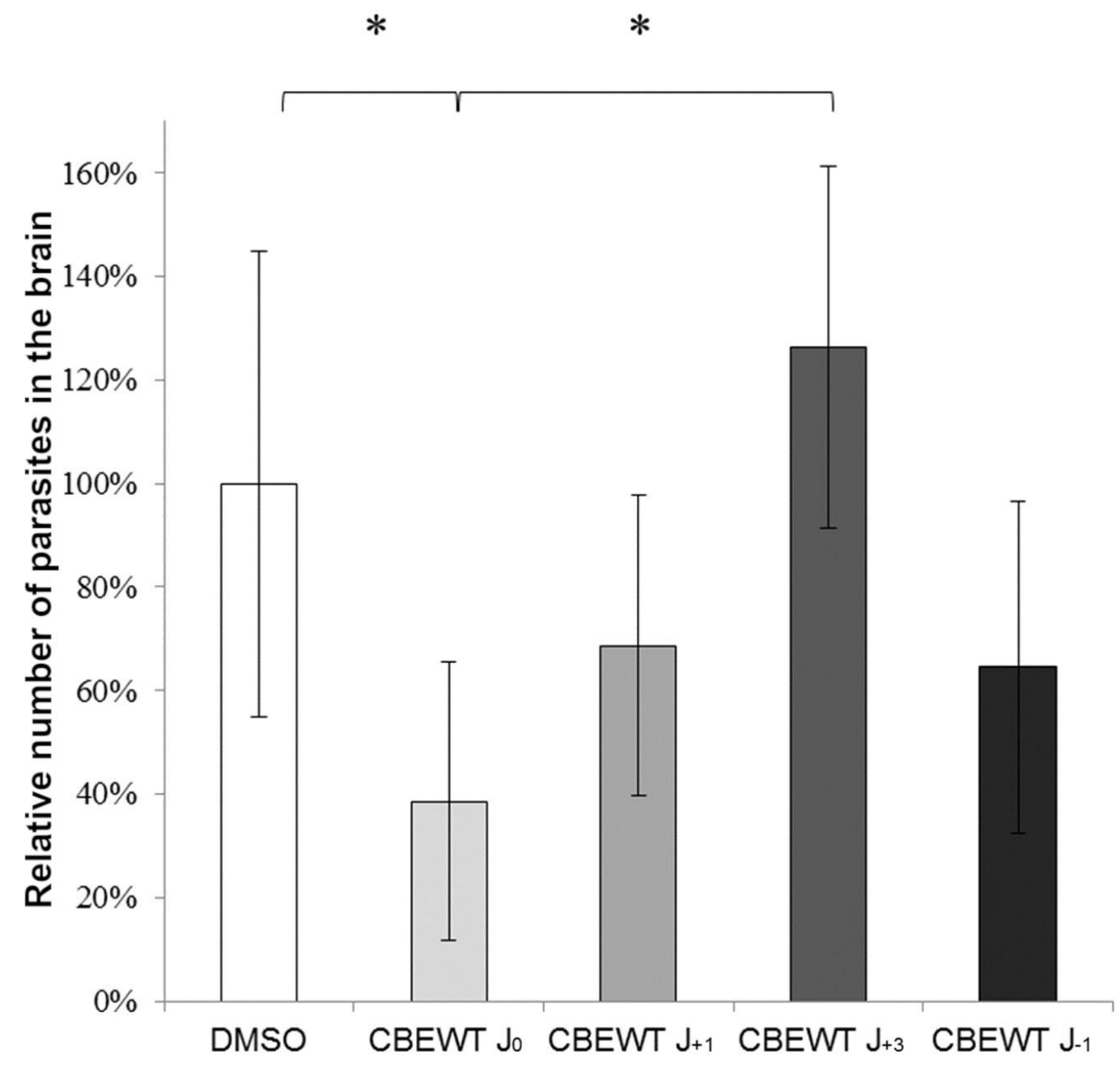

Figure 5: Relative number of parasites detected in brain in a chronic toxoplasmosis mouse model induced by ME49 strain tachyzoites. Ten mice per group were treated with the crude bark extract without tannins (CBEWT) 10 minutes after inoculation ( $\left.\mathrm{J}_{0}\right)$, 24 hours after inoculation $\left(J_{+1}\right), 72$ hours after inoculation $\left(J_{+3}\right)$ or 24 hours before inoculation $\left(\mathrm{J}_{-1}\right)\left({ }^{*} \mathrm{p}<0.05\right.$ compared to DMSO control group). 